\title{
Biographical and demographical variables as moderators in the prediction of turnover intentions
}

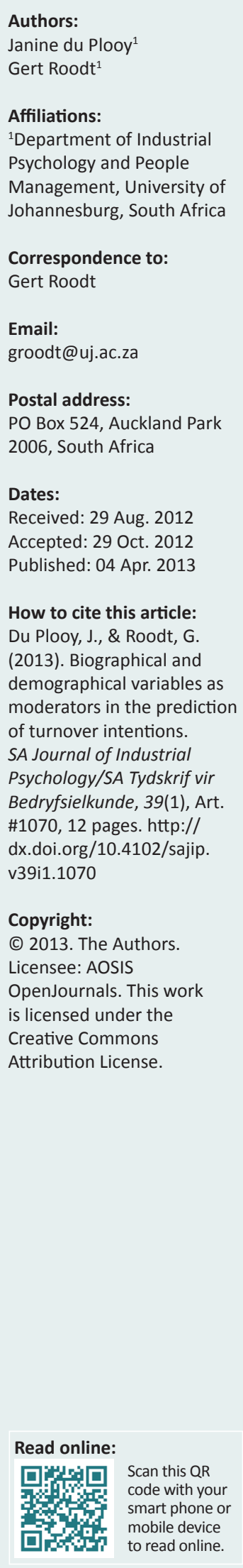

Orientation: The aim of the study was to explore the possible moderation effects of biographical and demographical variables on a prediction model of turnover intention (TI).

Research purpose: The main purpose of the study was to determine how biographical and demographical variables have an impact on predictors of turnover intentions.

Motivation for the study: Twenty-first century organisations face significant challenges in the management of talent and human capital. One in particular is voluntary employee turnover and the lack of appropriate business models to track this process.

Research design, approach, and method: A secondary data analysis (SDA) was performed in a quantitative research tradition on the cross-sectional survey sample $(n=2429)$. Data were collected from a large South African Information and Communication Technologies (ICT) sector company $(N=23134)$.

Main findings: The results of the study confirmed significant moderation effects regarding race, age, and marital status in the prediction equations of TIs.

Practical and managerial implications: Practical implications of the study suggested increased understanding of workforce diversity effects within the human resource (HR) value chain, with resultant evidence-based, employee retention strategies and interventions. Issues concerning talent management could also be addressed.

Contribution and value-add: The study described in this article took Industrial/Organisational (I/O) psychological concepts and linked them in unique combinations to establish better predictive validity of a more comprehensive turnover intentions model.

\section{Introduction}

Studies reporting results on reasons why employees choose to leave or stay with a particular organisation (Bothma \& Roodt, 2012; Du Plooy \& Roodt, 2010; Greyling \& Stanz, 2010; Griffeth, Hom \& Gaertner, 2000; Kotzé \& Roodt, 2005; Mendes \& Stander, 2011) are gaining importance and most of them focus on a set of negative consequences associated with employee turnover (Bluedorn, 1982; Greyling \& Stanz, 2010; Mobley, 1982; Roodt \& Bothma, 1997). Corporate sustainability issues are gaining momentum and an example of this is the behaviour of the modern and informed investor who no longer assesses the quality of the organisation at present, but the organisation's risk management and whether it has established sustainability strategies pertinent to its business (King III Report, 2009). As a result, employee turnover and its associated expenses for organisations are a key challenge (Bluedorn, 1982; Greyling \& Stanz, 2010; Roodt \& Bothma, 1997), specifically within a triple bottom line framework, which binds organisations to corporate strategies focused on profit, people and planet (King III Report, 2009).

The role of biographical and demographical variables in the prediction of TI remains unclear as Industrial and Organisational psychological literature provides very little substantial links between the predictive model of TIs (in the case of this study work engagement (WE), burnout (BO), organisational citizenship behaviour (OCB), work alienation (AL) and biographical and demographical variables. For this reason, it was strongly suggested in an earlier study by Du Plooy (2010) that the possible moderating effects of biographical and demographical variables in predictive models are tested. The suggested moderating effects of biographical and demographical variables in the prediction of TIs are depicted in Figure 1.

It is evident from Figure 1 that variables included in this model have not been related to turnover intentions in previous studies. A more comprehensive or complete understanding of factors contributing to TIs may result in more effective management strategies to curb employee turnover and HR risks as this contributes towards sustainability. The King III Report (2009) 


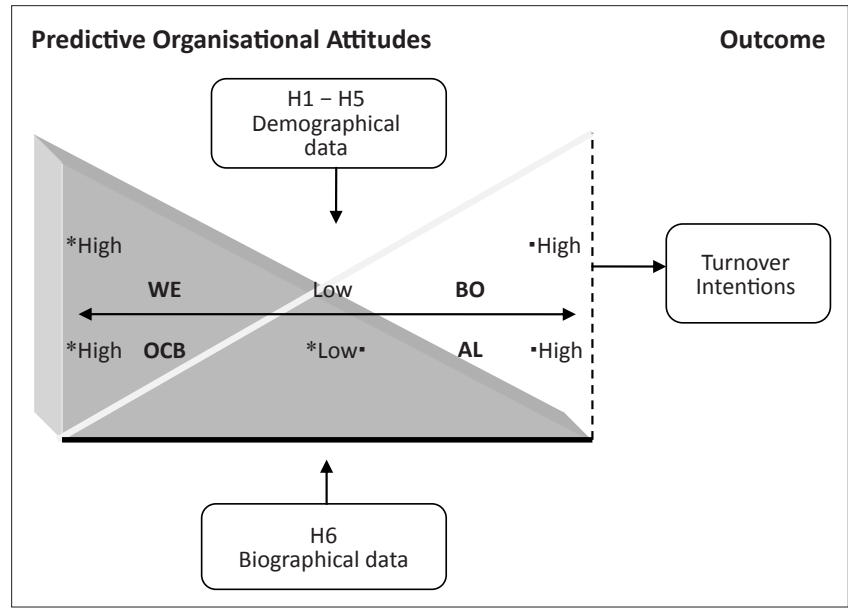

H1, Hypothesis 1 ; H5, Hypothesis 5; H6, Hypothesis 6; WE, Work engagement; OCB, Organisational citizenship behaviour; BO, Burnout; AL, Work alienation.

FIGURE 1: Research model of the predictive relationships with turnover intentions.

clearly states that boards of directors are responsible for the risk management and decision-making in terms of the triple bottom line - profit, people, planet - and to take into account the needs of future generations. Therefore, if employee turnover is better managed, people risks are reduced.

The main objective of the research is to determine whether certain biographical and demographical variables have a moderator ${ }^{1}$ effect on the predictive model of TIs. The predictive model of TI has been substantiated, that is, work engagement and organisational citizenship behaviour were negatively related to TI, and burnout and work alienation were positively related to TI (Du Plooy \& Roodt, 2010). It is on this predictive model of TIs that the possible moderator effects will be tested.

\section{A review of the literature}

Several authors (Bakker \& Demerouti, 2006; Jacobs, 2005; Lee \& Mitchell, 1994; Mobley, 1982; Morrell, Loan-Clarke, Arnold \& Wilkinson, 2008; Schaufeli \& Bakker, 2004; Zeffane, 1994) proposed and/or tested different predictive models for explaining TIs. These models have little in common and are based on different sets of assumptions and conceptualisations. The model of the current study (refer to Figure 1) follows a similar reasoning than those of Bakker and Demerouti (2006) and Schaufeli and Bakker (2004) where engagement is negatively related to turnover intentions and burnout is positively related to TIs.

In the two sections that follow, the moderating role of different biographical and demographic variables will be explained, based on existing literature. The biographical variables are gender, race groups, age, marital status and education level, whilst only one demographical variable, namely job level will be discussed.

Biographical variables as possible moderators in the prediction of TIs will now be examined. It is theorised that genders differ

1.A moderator is defined as '... a qualitative [e.g. gender] or quantitative [e.g. job level] variable which affects the direction and/or strength of the relation' between a predictor variable and an outcome or predicted variable (Baron \& Kenny, 1986, p. 1174). in how they respond to stimuli that may lead to different withdrawal behaviour patterns. Despite the fact that men and women share similar psychological structures and developmental processes during identity formation (Kroger, 1997), their spheres of work differ and are not rated as equal (Béteille, 2002). Several studies support moderator effects of gender in the prediction of TI (Almer \& Kaplan, 2002; Burke, Koyuncu \& Fiksenbaum, 2008; Cotton \& Tuttle, 1986; Coyne \& Ong, 2007; Harris, Andrews \& Kacmar, 2007; Karatepe \& Aleshinloye, 2009; Zhen \& Francesco, 2000). Men reported higher levels of depersonalisation than women (Almer \& Kaplan, 2002), resulting in the first research hypothesis to be tested.

Hypothesis 1: Gender moderates in the prediction of turnover intentions.

It is generally accepted that different culture groups follow different acculturation processes. As a consequence, different culture groups (including race groups) attach different values to work (Béteille, 2002). It is argued that the previously disadvantaged groups in South Africa show high job turnover (Jacobs, 2005; Thomas, 2002; Vallabh \& Donald, 2001) in an attempt to source the best possible positions and benefits. Another point of view is raised by Zatzick, Elvira, and Cohen (2003) who argued that employees belonging to the larger race group in organisations will tend to stay, owing to the supportive environment created by race group size. However, contradicting research results exist for the relationship between race and the predictive model of TI. In a study investigating possible antecedents of TIs, neither age, education levels, tenure, nor race had any significant impact (Fang, 2001). On the other hand, opposite results were found by Harris et al. (2007). Both gender and age were significantly and negatively linked to TIs, but not race. These contradictory findings guided the researchers to the second research hypothesis to be tested.

Hypothesis 2: Race moderates in the prediction of turnover intentions.

It is generally assumed that different age groups respond differently to stimuli, based on generational or age differences. Cotton and Tuttle (1986) in their meta-analysis of employee turnover, found that age was negatively related to employee turnover. Since then, other research findings on the relationship between age and the predictive model of TI showed that age relates negatively and significantly to an employee's intentions to vacate his or her position (Cropanzo, Rupp \& Byrne, 2003; Jacobs, 2005; Harris et al., 2007; Karatepe \& Aleshinloye, 2009; Rothrauff, Abraham, Bride \& Roman, 2011; Weisberg \& Kirschenbaum, 1991), resulting in the third research hypothesis to be investigated.

Hypothesis 3: Age moderates in the prediction of turnover intentions.

It is theorised that marital status may have a differentiating effect on how people choose to react in a particular situation, 
based on their different responsibilities and commitments. Cotton and Tuttle (1986) in their study found that married employees are less likely to resign than unmarried employees, because marital status and the accompanying responsibilities can be viewed as a constraint to resign (Chompookum \& Derr, 2004). Results on the relationship between marital status and the predictive model of TI found that employees with a spouse and/or children experiencing work-family conflict, advance more easily into organisational attitudes such as job satisfaction and turnover intentions than their single, childless colleagues (Huffman, Youngcourt, Payne \& Castro, 2008). Herewith, the fourth research hypothesis which was tested.

Hypothesis 4: Marital status moderates in the prediction of turnover intentions.

It is theorised that people with different education levels respond differently to particular situations, based on employment conditions and their own perceived market value. Cotton and Tuttle (1986) found that education level is positively related to employee turnover and possibly for the reason that Thomas (2002) highlighted, namely the better qualified people or candidates get the best job opportunities. However, Mauno, Kinnunen, and Ruokolainen (2007) found that the work engagement subcomponent dedication '...was more often experienced among professionals than nonprofessionals' (p. 164). The findings of Denton, Newton, and Bower (2008) are in line with those of Mauno et al. (2007) and stated that the group with additional professional qualifications reported higher WE and lower BO scores. Therefore, the highest educational levels indicated having an effect on the predictive model of TI. These findings guided the researchers to the fifth research hypothesis to be tested.

Hypothesis 5: Education level moderates in the prediction of turnover intentions.

The two demographical variables, job level and geographic region, as possible moderators of predictor variables in the prediction of TI will be examined next. It is argued that job level (which normally co-varies with age, educational level and tenure) may have a differential effect on how people respond to job-related stimuli. Chiu, Chung, Wu, and Ho (2009) found that employees in jobs with high job demands combined with low job control report turnover intentions more frequently. Findings showed that lower organisational levels relate negatively to an employee's intentions to vacate his position (Weisberg \& Kirschenbaum, 1991), whilst the results of Almer and Kaplan (2002) prove to be dissimilar. Organisational level has been related to BO (Almer \& Kaplan, 2002) and job position has been shown to be significantly related to WE (Kim, Shin \& Swanger, 2009). These incongruent findings guided the researchers to the second last research hypothesis to be tested.

Hypothesis 6: Job level moderates in the prediction of turnover intentions.
It is hypothesised that geographic region may have a differential effect on people's response to job-related stimuli. There are a host of possible reasons why people may be committed to locating in a particular region, such as owning property, availability of educational facilities, cost of living or even recreational facilities. No literature could be found that reported on moderation effects within this particular theoretical framework. The lack of literature guided the researchers to formulate the last hypothesis of this study.

Hypothesis 7: Geographic region moderates in the prediction of turnover intentions.

The abovementioned hypotheses can be graphically depicted as in Figure 1 above. The predictive model of TIs, that is, the WE and $\mathrm{BO}$ continuum and the constructs OCB and AL (Du Plooy \& Roodt, 2010), depicts that both biographic (Hypothesis 1 to Hypothesis 5) and demographic variables (Hypothesis 6 to Hypothesis 7) may moderate this relationship.

\section{Research design Research approach}

An SDA was performed on a subsection of the research in progress of Bothma and de Braine's cross-sectional field survey data. The data analyses followed a correlational and ex post facto approach.

\section{Research method}

A more detailed discussion of the research method can be found in an earlier article by Du Plooy and Roodt (2010, pp. 5-7) on which this section is based.

TABLE 1: Biographical and demographic characteristics of respondents $(n=2429)$.

\begin{tabular}{|c|c|c|c|}
\hline Variable & Category & $f$ & $\%$ \\
\hline \multirow[t]{2}{*}{ Gender } & Male & 1536 & 63.2 \\
\hline & Female & 893 & 36.8 \\
\hline \multirow[t]{4}{*}{ Race } & Black & 640 & 26.3 \\
\hline & White & 1070 & 44.1 \\
\hline & Coloured $\dagger$ & 395 & 16.3 \\
\hline & Asian or Indian & 324 & 13.3 \\
\hline \multirow[t]{4}{*}{ Age in years } & $19-29$ & 292 & 12.0 \\
\hline & $30-39$ & 960 & 39.5 \\
\hline & $40-49$ & 877 & 36.1 \\
\hline & $50+$ & 300 & 12.4 \\
\hline \multirow[t]{3}{*}{ Marital status } & Single & 511 & 21.0 \\
\hline & Married and cohabiting & 1678 & 69.1 \\
\hline & Divorced, or separated or widowed & 240 & 9.9 \\
\hline \multirow{4}{*}{$\begin{array}{l}\text { Highest academic } \\
\text { qualification }\end{array}$} & Matriculation or less & 988 & 40.7 \\
\hline & Post-school certificate or diploma & 479 & 19.7 \\
\hline & $\begin{array}{l}\text { National diploma or national higher } \\
\text { diploma }\end{array}$ & 653 & 26.9 \\
\hline & $\begin{array}{l}\text { Bachelor's degree or equivalent or } \\
\text { more }\end{array}$ & 309 & 12.7 \\
\hline \multirow[t]{3}{*}{ Job level } & Managers & 446 & 18.4 \\
\hline & Operational workers & 1334 & 54.9 \\
\hline & Specialist workers & 649 & 26.7 \\
\hline
\end{tabular}

$f$, Frequency

$\uparrow$, Coloured is a South African term to describe people of mixed racial descent. 


\section{Research respondents and sampling}

A heterogeneous work force of a large South African ICT sector company, consisting of operational and specialist employees up to middle management, represented the target population $(N=23134)$ for this study. A censusbased sampling approach was followed to ensure complete enumeration of the target population. The respondent sample $(n=2429)$ yielded a response rate of about $11 \%$.

In Table 1 the frequency and percentages of the respondents in relation to their biographic and demographic characteristics were presented. As indicated in the last column of Table 1, the majority of the respondents were male (63.2\%), White $(44.1 \%)$, and either between the ages of 30-39 years (39.5\%) or $40-49$ years $(36.1 \%)$. Most respondents were married and cohabiting (69.1\%), and indicated that their highest academic qualifications were matric or less $(40.7 \%)$, or having obtained a national diploma or national higher diploma $(26.9 \%)$. The managers and operational managers constituted $18.4 \%$ of the ICT company workforce, operational workers $54.9 \%$, and specialist workers $26.7 \%$.

\section{Measuring instruments}

The instruments used in the original study will be briefly discussed below.

Utrecht Work Engagement Scale (UWES-17). The 17-item version of the UWES was used to measure work engagement and consists of three subscales labelled Vigour (VI), Dedication (DE), and Absorption (AB) (Schaufeli \& Bakker, 2003; Schaufeli, Salanova, González-Romá \& Bakker, 2002). This version of the UWES was also successfully used in other work engagement research reported in the literature (Bakker, Schaufeli, Leiter \& Taris, 2008; Hakanen, Bakker \& Schaufeli, 2006; Hakanen, Schaufeli \& Ahola, 2008; Simpson, 2008). The current study reported a Cronbach alpha coefficient of .91 for the UWES-17.

Maslach Burnout Inventory-Human Services Survey (MBIHSS-20). The MBI-HSS-20 was used to measure burnout and consists of three subscales labelled Emotional Exhaustion (EE), Depersonalisation (DP), and Diminished Personal Accomplishment (PA) (Maslach \& Jackson, 1981; Maslach, Jackson \& Leiter, 1997; Vanheule, Rosseel \& Vlerick, 2007). Maslach and Jackson (1981) reported on a wide range of psychometric analyses on the MBI, which confirmed the reliability and validity of the instrument. The current study reported Cronbach alpha coefficients of .89 for emotional exhaustion .70 for depersonalisation and .71 for reduced personal accomplishment OCB (helping behaviour questions). Nine helping behaviour questions were used to measure OCB, which consisted of five items of the Helping Behaviour Scale (Van Dyne \& LePine, 1998) and four items from the Altruism dimension of the Citizenship Behaviour Scale (Smith, Organ \& Near, 1983). A Cronbach alpha coefficient of .86 for this scale was reported in the current study.

Alienation Scale. The five-item Alienation Scale (Banai, Reisel \& Probst, 2004) is based on the scale developed by
Korman, Wittig-Berman and Lang (1981), which was also used in a later study by Banai and Reisel (2007). Banai and Reisel reported a Cronbach alpha of .80 on the scale. The Cronbach alpha coefficient for AL in the current study was .81 .

Turnover Intentions Scale. The Turnover Intentions Scale was developed by Roodt (2004) as a measure for assessing employees' intentions of either staying with, or leaving an organisation. Two earlier studies (Jacobs, 2005; Martin, 2007) proved Roodt's (2004) questionnaire to be both reliable ( $\alpha=.913$ and $\alpha=.895$ respectively) and factually valid. A Cronbach alpha coefficient of .80 for TIs was reported in the current study.

For the current study, the authors focused on the data collected from the biographical and demographical forms. These were obtained by using a form contained in Bothma and de Braine's self-developed, web-based survey application, devoted to related questions and information available on the organisation's register. Salary reference numbers were linked to the organisational enumerations which provided the necessary biographical data (gender, race, age, marital status, and highest academic qualifications) and demographical data (job levels).

\section{Research procedure}

Du Plooy and Roodt (2010, p. 6) described the research procedure of the cross-sectional survey as follows: a research invitation was emailed to each employee within the sample, explaining the purpose and significance of the study and guaranteeing confidentiality. A web-link was added to each invitation, which provided direct access to a web-based survey application. The confidentiality of respondents was protected by means of complying with the company policy of using the employees' personnel numbers as identifiers, which were deleted from the database when the data was still in raw form. The responses were captured in a Structured Query Language (SQL) database that monitored the responses and restricted it to one per individual, in accordance with the personnel number. The data was immediately available and the SQL database sent out reminders to non-respondents.

\section{Statistical analysis}

The SPSS (version 18.0) programme was used for the statistical analyses. The inferential statistics performed included the use of ANOVAs followed by moderated multiple regression analyses (Pallant, 2007).

\section{Results}

In this study it was postulated that the predictive model of TI was moderated by certain biographical and demographical variables. The predictive model of this study was based on the regression equation of the prediction of TI $[\mathrm{TI}=1.836+0.495 \mathrm{AL}+0.318 \mathrm{BO}-0.180 \mathrm{WE}+0.091 \mathrm{OCB}]$ (du Plooy \& Roodt, 2010) and moderator effects were tested within this framework. 


\section{Moderator analyses of biographical variables}

The hierarchical, multiple regression method was used to test whether gender, race, age, marital status, and highest academic qualification acted as possible moderators in the prediction of TI. (Frazier, Tix \& Barron, 2004) suggested that multiple regressions were the preferred method for the testing of moderator effects. Firstly, ANOVAs were conducted on each of the 5 models for each variable presented, however as a result of space limitations these tables were not provided. The $F$ statistics of each of the models were statistically significant $(p \leq .001)$. A linear relationship between each of the predictor variables of each model and TI therefore exists. The multiple correlation coefficients $(R)$ between the predictor variables of Model 5 and the predicted variable (TI) are presented below in Table 2 to Table 6 . The model summaries reflect the inclusion of the biographical variables gender, race, age, marital status and highest academic qualification and their respective categories, in the multiple regression model of TI. The regression coefficients of Model 5 were provided and the variance each predictor variable contributed to the prediction of TI were shown, when the variance explained by the other variables in the model was controlled. The statistical parameters of gender, race, age, marital status, and highest academic qualification in Table 2 to Table 6 were used to formulate different equations to predict TI. Table 2 presents the possible moderation effect of gender on the other variables.

From the ANOVA analysis it follows that the regression model significantly predicted turnover intention, $F(9,2419)=399.801, p \leq .001$. The proportion variance explained $\left(R^{2}\right)$ for the model was .598 and adjusted $R^{2}$ was .596 . It is clear from Table 2 that there were statistically significant main effects for the different individual predictor variables $\mathrm{WE}, \mathrm{BO}, \mathrm{OCB}$ and AL (respectively $t=-7.614, p \leq .001$; $t=11.534, p \leq .001 ; t=4.769, p \leq .001 ; t=23.149$, $p \leq .001)$ and the gender category female $(t=-2.217, p=.027)$. However, no significant interaction terms were found between gender groups and any of the predictor variables in the model. The data did not support Hypothesis 1, which states that gender moderates the prediction of turnover intentions.
Table 3 presents the possible moderation effect of race group on the other variables in the model.

From the ANOVA analysis it followed that the regression model significantly predicted turnover intention, $F(19,2409)$ $=192.788, p \leq .001$. The proportion variance explained $\left(R^{2}\right)$ for the model was .603 and adjusted $R^{2}$ was .600 . It was evident from Table 3 that there were statistically significant main effects regarding the individual predictor variables $\mathrm{WE}$, $\mathrm{BO}, \mathrm{OCB}$ and AL (respectively $t=-6.204, p \leq .001 ; t=9.750$, $p \leq .001 ; t=3.259, p \leq .001 ; t=13.445, p \leq .001)$, but none for the different race group categories. However, race group categories did have several significant interaction terms in the model, namely between WE and the White group $(t=2.172$, $p=.030) ; \mathrm{BO}$ and the White group $(t=-2.690, p=.007) ; \mathrm{BO}$ and the Coloured group $(t=-2.060, p=.039)$; $\mathrm{BO}$ and the Asian/ Indian group $(t=-2.650, p=.008)$; OCB and the Coloured group $(t=-2.251, p=.024)$; and AL and the White group $(t=3.957, p \leq .001)$. Engagement and alienation levels were therefore dependent on whether you belonged to the White group and the level of burnout, or whether you belonged to the Coloured or Asian/Indian group in the prediction of TIs. The level of OCB was dependent on the Coloured group only when predicting TIs. Hypothesis 2, which states that race moderates the prediction of turnover intentions, was therefore supported by the data.

Table 4 presents the possible moderation effects between age groups and the other variables.

From the ANOVA analysis it followed that the regression model significantly predicted turnover intention, $F(19,2409)=192.474, p \leq .001$. The proportion variance explained $\left(R^{2}\right)$ for the model was .603 and adjusted $R^{2}$ was .600. As can be seen from Table 4 there were statistically significant main effects regarding the individual predictor variables $\mathrm{WE}, \mathrm{BO}, \mathrm{OCB}$ and $\mathrm{AL}$ (respectively $t=-3.258$, $p \leq .001 ; t=5.390, p \leq .001 ; t=2.912, p=.004 ; t=10.706$, $p \leq .001)$ and one age category (>50 years) $(t=-2.730$, $p=.006)$, but there was only one significant interaction term,

TABLE 2: Moderated multiple regression in terms of gender group.

\begin{tabular}{|c|c|c|c|c|c|c|c|c|}
\hline \multirow[t]{2}{*}{ Model 5} & \multicolumn{2}{|c|}{ Unstandardised Coefficients } & \multicolumn{3}{|c|}{ Standardised Coefficients } & \multirow[t]{2}{*}{$R$} & \multirow[t]{2}{*}{$R^{2}$} & \multirow[t]{2}{*}{ Adjusted $R^{2}$} \\
\hline & B & SE & Beta & $t$ & $p$ & & & \\
\hline (Constant) & 4.234 & 0.022 & - & 191.938 & $\leq .001 *$ & - & - & - \\
\hline WE & -0.195 & 0.026 & -0.178 & -7.614 & $\leq .001 *$ & - & - & - \\
\hline BO & 0.335 & 0.029 & 0.228 & 11.534 & $\leq .001 *$ & - & - & - \\
\hline OCB & 0.119 & 0.025 & 0.084 & 4.769 & $\leq .001 *$ & - & - & - \\
\hline AL & 0.487 & 0.021 & 0.517 & 23.149 & $\leq .001 *$ & - & - & - \\
\hline Female & -0.081 & 0.036 & -0.029 & -2.217 & $=.027 * *$ & - & - & - \\
\hline Female $\times$ WE & 0.027 & 0.041 & 0.016 & 0.672 & $=.501$ & - & - & - \\
\hline Female $\times \mathrm{BO}$ & -0.049 & 0.049 & -0.020 & -1.007 & $=.314$ & - & - & - \\
\hline Female $\times$ OCB & -0.064 & 0.041 & -0.027 & -1.568 & $=.117$ & - & - & - \\
\hline Female $\times \mathrm{AL}$ & 0.021 & 0.034 & 0.014 & 0.619 & $=.536$ & - & - & - \\
\hline Gender group & - & - & - & - & - & 0.773 & 0.598 & 0.596 \\
\hline
\end{tabular}

$\mathrm{B}$, regression coefficient; $\mathrm{SE}$, standard errors; $t$, $t$-test; $p$, probability value; $R$, multiple correlation coefficients; $R^{2}$, proportion variance explained, WE, Work engagement; $\mathrm{BO}$, Burnout; OCB, Organisational citizenship behaviour; AL, Work alienation.

Turnover intention is the dependent variable.

$*$, Statistically significant $(p \leq .001) ; * *$, Statistically significant $(p \leq .05)$ 
namely between OCB and $>50$ years $(t=-2.802, p=.005)$ when predicting TIs. Organisational citizenship behaviour level was therefore dependent on whether a person belonged to the age group of 50 and above when predicting TIs. Hypothesis 3, which states that age moderates the prediction of turnover intention was therefore supported by the data.
Table 5 presents the possible moderation effects of marital status and other variables.

From the ANOVA analysis it followed that the regression model significantly predicted turnover intention, $F(14,2414)$ $=257.847, p \leq .001$. The proportion variance explained $\left(R^{2}\right)$

TABLE 3: Moderated multiple regression in terms of race group.

\begin{tabular}{|c|c|c|c|c|c|c|c|c|}
\hline \multirow[t]{2}{*}{ Model 5} & \multicolumn{2}{|c|}{ Unstandardised Coefficients } & \multicolumn{3}{|c|}{ Standardised Coefficients } & \multirow[t]{2}{*}{$R$} & \multirow[t]{2}{*}{$R^{2}$} & \multirow[t]{2}{*}{ Adjusted $R^{2}$} \\
\hline & B & SE & Beta & $t$ & $p$ & & & \\
\hline (Constant) & 4.250 & 0.035 & - & 191.938 & $\leq .001 *$ & - & - & - \\
\hline WE & -0.231 & 0.037 & -0.211 & -6.203 & $\leq .001 *$ & - & - & - \\
\hline BO & 0.444 & 0.046 & 0.303 & 9.750 & $\leq .001 *$ & - & - & - \\
\hline OCB & 0.126 & 0.039 & 0.089 & 3.259 & $\leq .001^{*}$ & - & - & - \\
\hline AL & 0.407 & 0.030 & 0.432 & 13.445 & $\leq .001^{*}$ & - & - & - \\
\hline White & -0.065 & 0.045 & -0.024 & -1.455 & $=.146$ & - & - & - \\
\hline Coloured $\dagger$ & 0.033 & 0.057 & 0.009 & 0.580 & $=.562$ & - & - & - \\
\hline Asian or Indian & -0.103 & 0.062 & -0.026 & -1.655 & $=.098$ & - & - & - \\
\hline WE $\times$ White & 0.104 & 0.048 & 0.065 & 2.172 & $=.030 * *$ & - & - & - \\
\hline WE $\times$ Coloured $\dagger$ & 0.101 & 0.064 & 0.035 & 1.581 & $=.114$ & - & - & - \\
\hline WE $\times$ Asian or Indian & -0.070 & 0.067 & -0.022 & -1.052 & $=.293$ & - & - & - \\
\hline BO $\times$ White & -0.155 & 0.058 & -0.071 & -2.690 & $=.007 * *$ & - & - & - \\
\hline $\mathrm{BO} \times$ Coloured $\dagger$ & -0.156 & 0.076 & -0.041 & -2.060 & $=.039 * *$ & - & - & - \\
\hline OCB $\times$ White & -0.033 & 0.048 & -0.016 & -0.679 & $=.497$ & - & - & - \\
\hline $\mathrm{OCB} \times$ Coloured $\dagger$ & -0.144 & 0.064 & -0.039 & -2.251 & $=.024 * *$ & - & - & - \\
\hline $\mathrm{OCB} \times$ Asian or Indian & 0.048 & 0.071 & 0.012 & 0.685 & $=.494$ & - & - & - \\
\hline AL $\times$ White & 0.158 & 0.040 & 0.110 & 3.957 & $=.001 * *$ & - & - & - \\
\hline $\mathrm{AL} \times$ Coloured $\dagger$ & 0.085 & 0.052 & 0.037 & 1.626 & $=.104$ & - & - & \\
\hline $\mathrm{AL} \times$ Asian or Indian & 0.602 & 0.054 & 0.024 & 1.130 & $=.258$ & - & & - \\
\hline Race group & - & - & - & - & - & 0.777 & 0.603 & 0.600 \\
\hline
\end{tabular}

$\mathrm{B}$, regression coefficient; $\mathrm{SE}$, standard errors; $t$, $\mathrm{t}$-test; $p$, probability value; $R$, multiple correlation coefficients; $R^{2}$, proportion variance explained, WE, Work engagement; $\mathrm{BO}$, Burnout; $\mathrm{OCB}$, Organisational citizenship behaviour; AL, Work alienation.

Turnover intention is the dependent variable.

$\uparrow$, Coloured is a South African term to describe people of mixed racial descent.

$*$, Statistically significant $(p \leq .001) ; * *$, Statistically significant $(p \leq .05)$

TABLE 4: Moderated multiple regression in terms of age group.

\begin{tabular}{|c|c|c|c|c|c|c|c|c|}
\hline \multirow[t]{2}{*}{ Model 5} & \multicolumn{2}{|c|}{ Unstandardised Coefficients } & \multicolumn{3}{|c|}{ Standardised Coefficients } & \multirow[t]{2}{*}{$\boldsymbol{R}$} & \multirow[t]{2}{*}{$R^{2}$} & \multirow[t]{2}{*}{ Adjusted $R^{2}$} \\
\hline & B & SE & Beta & $t$ & $p$ & & & \\
\hline (Constant) & 4.226 & 0.054 & - & 77.982 & $\leq .001 *$ & - & - & - \\
\hline WE & -0.173 & 0.053 & -0.158 & -3.258 & $\leq .001^{*}$ & - & - & - \\
\hline BO & 0.359 & 0.067 & 0.244 & 5.390 & $\leq .001^{*}$ & - & - & - \\
\hline $\mathrm{OCB}$ & 0.150 & 0.052 & 0.107 & 2.912 & $\leq .004^{*}$ & - & - & - \\
\hline AL & 0.480 & 0.045 & 0.510 & 10.706 & $\leq .001^{*}$ & - & - & - \\
\hline $30-39$ & 0.055 & 0.061 & 0.020 & 0.900 & $=.368$ & - & - & - \\
\hline $40-49$ & -0.051 & 0.062 & -0.018 & -0.820 & $=.412$ & - & - & - \\
\hline 50 and over & -0.209 & 0.076 & -0.051 & -2.730 & $=.006^{*}$ & - & - & - \\
\hline WE $\times 30-39$ & -0.025 & 0.061 & -0.015 & -0.402 & $=.688$ & - & - & - \\
\hline WE $\times$ 40-49 & 0.021 & 0.063 & 0.011 & 0.333 & $=.739$ & - & - & - \\
\hline WE $\times 50$ and over & 0.020 & 0.082 & 0.006 & 0.240 & $=.810$ & - & - & - \\
\hline $\mathrm{BO} \times 30-39$ & -0.010 & 0.077 & -0.004 & -0.133 & $=.894$ & - & - & - \\
\hline BO × 40-49 & -0.060 & 0.077 & -0.025 & -0.780 & $=.436$ & - & - & - \\
\hline OCB $\times 30-39$ & -0.033 & 0.060 & -0.015 & -0.554 & $=.580$ & - & - & - \\
\hline OCB $\times 40-49$ & -0.076 & 0.061 & -0.031 & -1.242 & $=.214$ & - & - & - \\
\hline $\mathrm{OCB} \times 50$ and over & -0.220 & 0.078 & -0.052 & -2.802 & $=.005^{* *}$ & - & - & - \\
\hline$A L \times 30-39$ & -0.016 & 0.052 & -0.010 & -0.304 & $=.761$ & - & - & - \\
\hline$A L \times 40-49$ & 0.015 & 0.053 & 0.009 & 0.291 & $=.771$ & - & - & - \\
\hline $\mathrm{AL} \times 50$ and over & 0.067 & 0.065 & 0.026 & 1.026 & $=.305$ & - & - & - \\
\hline Age group & - & - & - & - & - & 0.776 & 0.603 & 0.600 \\
\hline
\end{tabular}

$\mathrm{B}$, regression coefficient; $\mathrm{SE}$, standard errors; $t$, t-test; $p$, probability value; $R$, multiple correlation coefficients; $R^{2}$, proportion variance explained, WE, Work engagement; $\mathrm{BO}$, Burnout; OCB, Organisational citizenship behaviour; AL, Work alienation.

Turnover intention is the dependent variable.

$*$, Statistically significant $(p \leq .001) ; * *$, Statistically significant $(p \leq .05)$ 
TABLE 5: Moderated multiple regression in terms of marital status.

\begin{tabular}{|c|c|c|c|c|c|c|c|c|}
\hline \multirow[t]{2}{*}{ Model 5} & \multicolumn{2}{|c|}{ Unstandardised Coefficients } & \multicolumn{3}{|c|}{ Standardised Coefficients } & \multirow[t]{2}{*}{$\boldsymbol{R}$} & \multirow[t]{2}{*}{$R^{2}$} & \multirow[t]{2}{*}{ Adjusted $R^{2}$} \\
\hline & B & SE & Beta & $t$ & $p$ & & & \\
\hline (Constant) & 4.185 & 0.039 & - & 107.743 & $\leq .001 *$ & - & - & - \\
\hline WE & -0.159 & 0.040 & -0.145 & -3.997 & $\leq .001 *$ & - & - & - \\
\hline BO & 0.414 & 0.049 & 0.282 & 8.364 & $\leq .001^{*}$ & - & - & - \\
\hline OCB & 0.108 & 0.039 & 0.076 & 2.750 & $\leq .006 * *$ & - & - & - \\
\hline AL & 0.433 & 0.033 & 0.460 & 12.988 & $\leq .001^{*}$ & - & - & - \\
\hline Married and cohabiting & 0.039 & 0.044 & 0.013 & 0.876 & $=.381$ & - & - & - \\
\hline $\begin{array}{l}\text { Divorced or separated or } \\
\text { widowed }\end{array}$ & -0.058 & 0.068 & -0.013 & -0.846 & $=.398$ & - & - & - \\
\hline $\begin{array}{l}\text { WE } \times \text { Married and } \\
\text { cohabiting }\end{array}$ & -0.039 & 0.047 & -0.029 & -0.831 & $=.406$ & - & - & - \\
\hline $\begin{array}{l}\text { WE } \times \text { Divorced or separated } \\
\text { or widowed }\end{array}$ & 0.058 & 0.073 & 0.016 & 0.790 & $=.430$ & - & - & - \\
\hline $\begin{array}{l}\text { BO } \times \text { Married and } \\
\text { cohabiting }\end{array}$ & -0.127 & 0.057 & -0.072 & -2.228 & $=.026 * *$ & - & - & - \\
\hline $\begin{array}{l}\text { BO } \times \text { Divorced or separated } \\
\text { or widowed }\end{array}$ & -0.088 & 0.087 & -0.019 & -1.043 & $=.297$ & - & - & - \\
\hline $\begin{array}{l}\text { OCB } \times \text { Married and } \\
\text { cohabiting }\end{array}$ & -0.025 & 0.046 & -0.015 & -0.545 & $=.586$ & - & - & - \\
\hline $\begin{array}{l}\text { OCB } \times \text { Divorced or } \\
\text { separated or widowed }\end{array}$ & 0.009 & 0.077 & 0.002 & 0.110 & $=.912$ & - & - & - \\
\hline AL $\times$ Married and cohabiting & 0.072 & 0.039 & 0.063 & 1.854 & $=.064$ & - & - & - \\
\hline $\begin{array}{l}\text { AL } \times \text { Divorced or separated } \\
\text { or widowed }\end{array}$ & 0.152 & 0.061 & 0.051 & 2.476 & $=.013 * *$ & - & - & - \\
\hline Marital status & - & - & - & - & - & 0.774 & 0.599 & 0.597 \\
\hline
\end{tabular}

$\mathrm{B}$, regression coefficient; $\mathrm{SE}$, standard errors; $t$, t-test; $p$, probability value; $R$, multiple correlation coefficients; $R^{2}$, proportion variance explained, WE, Work engagement; $\mathrm{BO}$, Burnout; OCB, Organisational citizenship behaviour; AL, Work alienation.

Turnover intention is the dependent variable.

$*$, Statistically significant $(p \leq .001) ; * *$, Statistically significant $(p \leq .05)$

for the model was .599 and adjusted $R^{2}$ was .597 . It is evident from Table 5 that there were statistically significant main effects regarding the individual predictor variables WE, $\mathrm{BO}, \mathrm{OCB}$ and AL (respectively $t=-3.997, p \leq .001 ; t=8.364$, $p \leq .001 ; t=2.750, p=.006 ; t=12.988, p \leq .001)$, but not for any of the marital status categories. Two significant interaction terms were found, namely between $\mathrm{BO}$ and married or cohabitating $(t=-2.228, p=.026)$ and AL and divorced or separated $(t=2.476, p=.013)$. These findings therefore suggested that the level of burnout was dependent on whether a person was married or cohabitating and the level of alienation on whether a person was divorced or separated. Hypothesis 4, which states that marital status moderates the prediction of turnover intentions was therefore supported by the data.

Table 6 presents possible moderation effects between education levels categories and other variables in the model.

From the ANOVA analysis it followed that the regression model significantly predicted turnover intention, $F(19,2409)$ $=191.681, p \leq .001$. The proportion variance explained $\left(R^{2}\right)$ for the model was .602 and adjusted $R^{2}$ was .599. It is evident from Table 6 that there were statistically significant main effects regarding the individual predictor variables $\mathrm{WE}$, $\mathrm{BO}, \mathrm{OCB}$ and AL (respectively $t=-6.207, p \leq .001 ; t=7.875$, $p \leq .001 ; t=3.079, p=.002 ; t=19.695, p \leq .001)$ and the academic qualification level categories post-school certificate or diploma $(t=2.461, p=.014)$; national or higher diploma $(t=3.307, p \leq .001)$ and bachelor's degree or its equivalent $(t=2.567, p=.010)$, but that there were no significant interaction effects between academic qualification categories and the predictor variables in the model. The data therefore did not support Hypothesis 5, which states that academic qualification moderates the prediction of turnover intentions.

\section{Moderator analyses of demographical variables}

As in the case of the first group of hypotheses, a (similar) hierarchical multiple regression method was used to test whether job level and geographical region acts as a moderator in the prediction of TI. Stating the procedure briefly, ANOVAs were conducted on each of the 5 models for the variable and significant levels for the $F$ statistics $(p \leq .001)$ were obtained for each of the models, suggesting that a linear relationship between the predictor variable and TI did exist. The correlation coefficients $(R)$ between the predictor variable of Model 5 and the predicted variable (TI) were presented. The model summaries presented reflect the inclusion of the demographical variables job level and geographical region and their respective categories, in the multiple regression models of TI. The regression coefficients of Model 5 will be provided in the next two tables (Table 7 to Table 8) as well as the variance each predictor variable contributed to prediction of TI. Table 7 below shows the possible moderation effects of job level and other variables in the model.

From the ANOVA analysis it followed that the regression model significantly predicted turnover intention, $F(14,2414)=256.741, p \leq .001$. The proportion variance explained $\left(R^{2}\right)$ for the model was .598 and adjusted $R^{2}$ was .596 . As can be seen from Table 7 the individual predictor variables $\mathrm{WE}, \mathrm{BO}$ and AL (respectively $t=-3.828, p \leq .001 ; t=5.754$, $p \leq .001 ; t=12.217, p \leq .001$ ) had statistically significant main effects, but there were no significant interaction terms 
TABLE 6: Moderated multiple regression in terms of educational levels.

\begin{tabular}{|c|c|c|c|c|c|c|c|c|}
\hline \multirow[t]{2}{*}{ Model 5} & \multicolumn{2}{|c|}{ Unstandardised Coefficients } & \multicolumn{3}{|c|}{ Standardised Coefficients } & \multirow[t]{2}{*}{$R$} & \multirow[t]{2}{*}{$R^{2}$} & \multirow[t]{2}{*}{ Adjusted $R^{2}$} \\
\hline & B & SE & Beta & $t$ & $p$ & & & \\
\hline (Constant) & 4.120 & 0.028 & & 149.736 & $\leq .001 *$ & - & - & - \\
\hline WE & -0.185 & 0.030 & -0.169 & -6.207 & $\leq .001 *$ & - & - & - \\
\hline BO & 0.288 & 0.037 & 0.196 & 7.875 & $\leq .001 *$ & - & - & - \\
\hline $\mathrm{OCB}$ & 0.093 & 0.030 & 0.066 & 3.079 & $\leq .002 *$ & - & - & - \\
\hline AL & 0.501 & 0.025 & 0.533 & 19.695 & $\leq .001^{*}$ & - & - & - \\
\hline $\begin{array}{l}\text { Post-school certificate or } \\
\text { diploma }\end{array}$ & 0.118 & 0.048 & 0.035 & 2.461 & $\leq .014^{*}$ & - & - & - \\
\hline National or higher diploma & 0.144 & 0.043 & 0.047 & 3.307 & $\leq .001 *$ & - & - & - \\
\hline $\begin{array}{l}\text { Bachelor's degree or } \\
\text { equivalent or more }\end{array}$ & 0.149 & 0.058 & 0.037 & 2.567 & $\leq .010^{*}$ & - & - & - \\
\hline $\begin{array}{l}\text { WE } \times \text { Post-school certificate } \\
\text { or diploma }\end{array}$ & 0.013 & 0.054 & 0.005 & 0.248 & $=.804$ & - & - & - \\
\hline $\begin{array}{l}\text { WE } \times \text { National or higher } \\
\text { diploma }\end{array}$ & 0.016 & 0.050 & 0.007 & 0.319 & $=.750$ & - & - & - \\
\hline $\begin{array}{l}\text { WE } \times \text { Bachelor's degree or } \\
\text { equivalent or more }\end{array}$ & -0.012 & 0.064 & -0.004 & -0.182 & $=.855$ & - & - & - \\
\hline $\begin{array}{l}\text { BO } \times \text { Post-school certificate } \\
\text { or diploma }\end{array}$ & 0.039 & 0.067 & 0.012 & 0.606 & $=.545$ & - & - & - \\
\hline $\begin{array}{l}\text { BO } \times \text { National or higher } \\
\text { diploma }\end{array}$ & 0.105 & 0.057 & 0.037 & 1.848 & $=.065$ & - & - & - \\
\hline $\begin{array}{l}\text { BO } \times \text { Bachelor's degree or } \\
\text { equivalent or more }\end{array}$ & -0.011 & 0.077 & -0.003 & -0.139 & $=.889$ & - & - & - \\
\hline $\begin{array}{l}\text { OCB } \times \text { Post-school } \\
\text { certificate or diploma }\end{array}$ & -0.079 & 0.054 & -0.024 & -1.458 & $=.145$ & - & - & - \\
\hline $\begin{array}{l}\text { OCB } \times \text { National or higher } \\
\text { diploma }\end{array}$ & 0.067 & 0.049 & 0.025 & 1.386 & $=.166$ & - & - & - \\
\hline $\begin{array}{l}\text { OCB } \times \text { Bachelor's degree or } \\
\text { equivalent or more }\end{array}$ & 0.000 & 0.064 & 0.000 & 0.007 & $=.994$ & - & - & - \\
\hline $\begin{array}{l}\text { AL } \times \text { Post-school certificate } \\
\text { or diploma }\end{array}$ & -0.049 & 0.045 & -0.024 & -1.087 & $=.277$ & - & - & - \\
\hline $\begin{array}{l}\text { AL } \times \text { National or higher } \\
\text { diploma }\end{array}$ & -0.009 & 0.041 & -0.005 & -0.211 & $=.833$ & - & - & - \\
\hline $\begin{array}{l}\text { AL } \times \text { Bachelor's degree or } \\
\text { equivalent or more }\end{array}$ & 0.057 & 0.053 & 0.022 & 1.076 & $=.282$ & - & - & - \\
\hline
\end{tabular}

$\mathrm{B}$, regression coefficient; $\mathrm{SE}$, Standard errors; $t$, t-test; $p$, probability value; $R$, multiple correlation coefficients; $R^{2}$, proportion variance explained, WE, Work engagement; $\mathrm{BO}$, Burnout; OCB, Organisational citizenship behaviour; AL, Work alienation.

Turnover intention is the dependent variable.

$*$, Statistically significant $(p \leq .001) ; * *$, Statistically significant $(p \leq .05)$

TABLE 7: Moderated multiple regression in terms of job levels.

\begin{tabular}{|c|c|c|c|c|c|c|c|c|}
\hline \multirow[t]{2}{*}{ Model 5} & \multicolumn{2}{|c|}{ Unstandardised Coefficients } & \multicolumn{3}{|c|}{ Standardised Coefficients } & \multirow[t]{2}{*}{$R$} & \multirow[t]{2}{*}{$R^{2}$} & \multirow[t]{2}{*}{ Adjusted $R^{2}$} \\
\hline & B & SE & Beta & $t$ & $p$ & & & \\
\hline (Constant) & 4.297 & 0.045 & - & 95.326 & $\leq .001 *$ & - & - & - \\
\hline WE & -0.234 & 0.061 & -0.214 & -3.828 & $\leq .001 *$ & - & - & - \\
\hline BO & 0.301 & 0.052 & 0.205 & 5.754 & $\leq .001 *$ & - & - & - \\
\hline OCB & 0.103 & 0.055 & 0.073 & 1.886 & $=.059$ & - & - & - \\
\hline AL & 0.519 & 0.043 & 0.552 & 12.217 & $\leq .001 *$ & - & - & - \\
\hline Operational workers & -0.111 & 0.051 & -0.041 & -2.179 & $=.029 * *$ & - & - & - \\
\hline Specialist workers & -0.088 & 0.057 & -0.029 & -1.539 & $=.124$ & - & - & - \\
\hline WE $\times$ Operational workers & 0.072 & 0.066 & 0.052 & 1.086 & $=.278$ & - & - & - \\
\hline WE $\times$ Specialist workers & 0.011 & 0.073 & 0.005 & 0.154 & $=.878$ & - & - & - \\
\hline $\mathrm{BO} \times$ Operational workers & 0.020 & 0.061 & 0.011 & 0.334 & $=.738$ & - & - & - \\
\hline BO $\times$ Specialist workers & 0.027 & 0.070 & 0.009 & 0.393 & $=.694$ & - & - & - \\
\hline OCB $\times$ Operational workers & -0.020 & 0.060 & -0.011 & -0.339 & $=.735$ & - & - & - \\
\hline $\mathrm{OCB} \times$ Specialist workers & 0.013 & 0.067 & 0.005 & 0.195 & $=.846$ & - & - & - \\
\hline AL $\times$ Specialist workers & -0.018 & 0.053 & -0.010 & -0.340 & $=.734$ & - & - & - \\
\hline Job levels & - & - & - & - & - & 0.773 & 0.598 & 0.596 \\
\hline
\end{tabular}

$\mathrm{B}$, regression coefficient; $\mathrm{SE}$, standard errors; $t$, t-test; $p$, probability value; $R$, multiple correlation coefficients; $R^{2}$, proportion variance explained, WE, Work engagement; $\mathrm{BO}$, Burnout; OCB, Organisational citizenship behaviour; AL, Work alienation.

Turnover intention is the dependent variable.

$*$, Statistically significant $(p \leq .001) ; * *$, Statistically significant $(p \leq .05)$

between job level categories and the predictor variables included in the model. The data therefore did not support Hypothesis 6, which states that job level moderates the prediction of turnover intentions. Table 8 below shows the possible moderation effects of geographical region and other variables in the model. 
TABLE 8: Moderated multiple regression in terms of geographic region.

\begin{tabular}{|c|c|c|c|c|c|c|c|c|}
\hline \multirow[t]{2}{*}{ Model 5} & \multicolumn{2}{|c|}{ Unstandardised Coefficients } & \multicolumn{3}{|c|}{ Standardised Coefficients } & \multirow[t]{2}{*}{$R$} & \multirow[t]{2}{*}{$R^{2}$} & \multirow[t]{2}{*}{ Adjusted $R^{2}$} \\
\hline & B & SE & Beta & $\mathbf{t}$ & Significance & & & \\
\hline (Constant) & 4.103 & 0.080 & - & 51.607 & $\leq .001^{*}$ & - & - & - \\
\hline WE & -0.161 & 0.090 & -0.147 & -1.793 & $=.073$ & - & - & - \\
\hline BO & 0.275 & 0.110 & 0.187 & 2.508 & $=.012 * *$ & - & - & - \\
\hline OCB & -0.043 & 0.089 & -0.030 & -0.484 & $=.629$ & - & - & - \\
\hline AL & 0.504 & 0.071 & 0.535 & 7.093 & $\leq .001 *$ & - & - & - \\
\hline Corporate head office & 0.127 & 0.087 & 0.040 & 1.457 & $=.145$ & - & - & - \\
\hline Eastern & -0.014 & 0.094 & -0.003 & -0.149 & $=.881$ & - & - & - \\
\hline Gauteng central & 0.181 & 0.090 & 0.052 & 2.009 & $=.045 * *$ & - & - & - \\
\hline Northeast & 0.085 & 0.093 & 0.022 & 0.915 & $=.360$ & - & - & - \\
\hline Southern & 0.063 & 0.106 & 0.012 & 0.601 & $=.548$ & - & - & - \\
\hline Western & 0.118 & 0.090 & 0.034 & 1.311 & $=.190$ & - & - & - \\
\hline WE*Corporate head office & 0.017 & 0.098 & 0.008 & 0.173 & $=.863$ & - & - & - \\
\hline WE*Eastern & -0.004 & 0.106 & -0.001 & -0.040 & $=.968$ & - & - & - \\
\hline WE*Northeast & -0.084 & 0.106 & -0.026 & -0.789 & $=.430$ & - & - & - \\
\hline WE*Southern & 0.077 & 0.123 & 0.017 & 0.630 & $=.529$ & - & - & - \\
\hline WE*Western & 0.007 & 0.101 & 0.003 & 0.068 & $=.946$ & - & - & - \\
\hline BO*Corporate head office & 0.090 & 0.119 & 0.030 & 0.759 & $=.448$ & - & - & - \\
\hline BO*Eastern & 0.009 & 0.127 & 0.002 & 0.072 & $=.943$ & - & - & - \\
\hline BO*Gauteng Central & -0.019 & 0.123 & -0.006 & -0.156 & $=.876$ & - & - & - \\
\hline BO*Northeast & 0.119 & 0.127 & 0.030 & 0.933 & $=.351$ & - & - & - \\
\hline BO*Southern & 0.012 & 0.144 & 0.002 & 0.085 & $=.933$ & - & - & - \\
\hline BO*Western & 0.009 & 0.124 & 0.003 & 0.075 & $=.941$ & - & - & - \\
\hline OCB*Corporate head office & 0.116 & 0.097 & 0.041 & 1.196 & $=.232$ & - & - & - \\
\hline OCB*Eastern & 0.118 & 0.107 & 0.028 & 1.102 & $=.270$ & - & - & - \\
\hline OCB*Gauteng Central & 0.163 & 0.099 & 0.051 & 1.644 & $=.100$ & - & - & - \\
\hline OCB*Northeast & 0.253 & 0.103 & 0.067 & 2.454 & $=.014$ & - & - & - \\
\hline OCB*Southern & 0.095 & 0.118 & 0.018 & 0.809 & $=.419$ & - & - & - \\
\hline AL*Eastern & -0.013 & 0.084 & -0.005 & -0.157 & $=.875$ & - & - & - \\
\hline AL*Gauteng Central & -0.049 & 0.081 & -0.022 & -0.609 & $=.542$ & - & - & - \\
\hline AL*Northeast & -0.061 & 0.084 & -0.022 & -0.728 & $=.466$ & - & - & - \\
\hline$A L *$ Southern & 0.095 & 0.099 & 0.025 & 0.958 & $=.338$ & - & - & - \\
\hline AL*Western & -0.014 & 0.081 & -0.006 & -0.167 & $=.867$ & - & - & - \\
\hline Geographic region & - & - & - & - & - & 0.776 & 0.602 & 0.596 \\
\hline
\end{tabular}

$\mathrm{B}$, regression coefficient; $\mathrm{SE}$, standard errors; $t$, t-test; $p$, probability value; $R$, multiple correlation coefficients; $R^{2}$, proportion variance explained, $\mathrm{WE}$, Work engagement; $\mathrm{BO}$, Burnout; OCB, Organisational citizenship behaviour; AL, Work alienation.

Turnover intention is the dependent variable.

$*$, Statistically significant $(p \leq .001) ; * *$, Statistically significant $(p \leq .05)$

From the ANOVA analysis it followed that the regression model significantly predicted turnover intention, $F(34,2394)=106.404, p \leq .001$. The proportion variance explained $\left(R^{2}\right)$ for the model was .602 and adjusted $R^{2}$ was .596. It is evident from Table 8 that only the individual predictor variables $\mathrm{BO}, \mathrm{AL}$ and region Gauteng Central presented significant main effects (respectively $t=2.508$, $p=.012 ; t=7.093, p \leq .001 ; t=2.009, p=.045)$, but there were no significant or interpretable interaction terms between the geographical region categories and the predictor variables in the model. The data therefore did not support Hypothesis 7 which states that geographical region moderates in the prediction of turnover intention.

\section{Discussion}

The aim of this paper was to establish whether selected biographical and demographical variables possibly have a moderating effect on predictor variables work engagement, burnout, OCB, and work alienation in the prediction of TI. To the researchers' knowledge this is the first study that include the effect biographical and demographical variables may have on $\mathrm{WE}, \mathrm{BO}, \mathrm{OCB}$ and $\mathrm{AL}$ as predictors of TI. Several biographical moderators were established in controlling an effect in the predictive model of TI - these were race, age, and marital status. Two demographic variables, namely job level and geographic region, were tested for a moderator effect in the predictive model of TI, and were found to be a non-statistically significant moderator.

\section{Summary of results}

In the current study biographical (gender, race, age, marital status, and academic qualification) and demographical variables (job level and geographic region) are related to variables (as portrayed in Figure 1) such as WE, BO, OCB and $\mathrm{AL}$ in the prediction of turnover intentions. The following paragraphs provide a summary of these findings and possible explanations. 
Hypothesis 1 states that gender moderates the prediction of turnover intentions. The current study's findings, however, do not support Hypothesis 1 and subsequently contradict the findings of previous studies (Almer \& Kaplan, 2002; Burke, Koyuncu, \& Fiksenbaum, 2008; Cotton \& Tuttle, 1986; Coyne \& Ong, 2007; Harris, Andrews \& Kacmar, 2007; Karatepe \& Aleshinloye, 2009; Zhen \& Francesco, 2000) that reported moderation effects of gender in predicting TIs. This result is unexpected, and cannot be easily explained. The most plausible explanation would be that both genders are exposed to the same stimuli (practices and procedures) in their work environment and consequently do not differ in their response to these factors.

Hypothesis 2 states that race moderates the prediction of turnover intention. The findings of this study support Hypothesis 2 and also confirm research conducted previously by Fang (2001) and Harris et al. (2007). It is also argued by Jacobs (2005); Thomas (2002); Vallabh and Donald (2001) that previously disadvantaged groups exhibit higher job mobility. The current study found that engagement and alienation levels are dependent on whether you belonged to the White group and burnout levels whether you belong to the White, Coloured or Asian and Indian groups in the prediction of TIs. Level of OCB is dependent on the Coloured group only when predicting TIs. These differences may relate to employment market conditions where groups respond differently to workplace conditions in terms of their coping styles, by either displaying citizenship behaviours, becoming engaged or alienated, or in extreme cases, experience burnout.

Hypothesis 3 states that age moderates the prediction of turnover intention. This study supports Hypothesis 3, where OCB level is dependent on whether a person belonged to the age group of 50 and above when predicting TIs. The current study therefore supports previous research findings on the relationship between age and turnover intentions, showing that age is negatively related to an employee's intentions to vacate his position (Cotton \& Tuttle, 1986; Cropanzo et al., 2003; Jacobs, 2005; Harris et al., 2007; Karatepe \& Aleshinloye, 2009; Rothrauff et al., 2011; Weisberg \& Kirschenbaum, 1991). The stated hypothesis is, in this case, only applicable to the age group of 50 and above. This indicates that the older age group may be more cautious to resign because of the difficulty of finding alternative employment.

Hypothesis 4 states that marital status moderates the prediction of turnover intentions. Hypothesis 4 is supported in this study where the level of burnout is dependent on whether a person is married or cohabitating (probably based on conflicting work and private life demands) and the level of alienation based on whether a person is divorced or separated (probably as a result of too many demands and consequential withdrawal behaviour) when predicting TIs. This confirms research by Cotton and Tuttle (1986), who argued that married employees are less likely to resign than unmarried employees, because marital status and the accompanying responsibilities can be viewed as a constraint to resign (Chompookum \& Derr, 2004). To the contrary, research by Huffman et al. (2008) reported that employees with a spouse and/or children who experienced work versus family conflict, advanced more easily into organisational attitudes, such as job satisfaction and turnover intentions than their single, childless colleagues.

Hypothesis 5 states that education levels moderate the prediction of turnover intentions. The current study could not establish any support for Hypothesis 5. Cotton and Tuttle (1986) reported that education level is positively related to employee turnover, because the better qualified a person is, the better their possible job opportunities (Thomas, 2002). Mauno et al. (2007) found that the work engagement subcomponent dedication '...was more often experienced among professionals than non-professionals' (p. 164). The findings of Denton et al. (2008) are in line with those of Mauno et al. (2007) who found that the group with additional professional qualifications reported higher WE and lower BO scores. This relationship between education level and turnover intentions may however, only be visible under normal market conditions, but South Africa's 'abnormal' market conditions, where Black Economic Empowerment and other restrictive labour legislation and associated practices prevent normal market forces to come into play, may be the reason for not finding support for Hypothesis 5 .

Hypothesis 6 states that job level moderates the prediction of turnover intentions. The current study could not establish any support for Hypothesis 6. Findings by Weisberg and Kirschenbaum (1991) showed that lower organisational levels relate negatively and significantly to an employee's intentions to resign.

Organisational levels with high demands have been related to BO and turnover intentions (Almer \& Kaplan, 2002; Chiu et al., 2009), but job position also showed to be significantly related to WE (Kim et al., 2009). It is known that job levels and education levels normally co-vary to some degree. A similar explanation may be provided as in the case of Hypothesis 5 above, where restrictive labour legislation and associated practices distort and prevent normal market forces to come into play.

Hypothesis 7 states that geographic region moderates the prediction of turnover intentions. The current study could not establish any support for Hypothesis 7. No previous literature could shed any light on this finding, but it was theorised that geographic region may be related to differences in cost of living, educational facilities, property ownership and recreational facilities, which may influence employees' choices to locate in a particular region.

\section{Managerial implications and recommendations}

The study explored various antecedents of TI and included the biographical and demographical differences that tended to influence the prediction of TI within this sample group. A practical contribution of this study will be an increased understanding of the implications with regard to workforce diversity and the prediction of such trends in the South African ICT sector. These antecedents of TI could therefore act as identifiers and applied in evidence-based recruitment and selection procedures, retention strategies and talent 
management interventions. Human resources practices could benefit from the predictive validity this study provides to improve on sustainability strategies and could be used in the reduction of employee turnover or at least in the accurate anticipation of employee turnover and associated expenses. The practical implications of the study will, therefore, impact on all the HR value chain activities, ranging from employee entrance level right through to employee exit level thereby suggesting that no 'one size fits all strategy' could be imposed. HR practices should therefore differentiate in terms of these moderating variables. A Chinese study, viewed as being knowledgeable about organisational attitudes and demography of employees in the prediction of TIs as managerially empowering (Zhen \& Francesco, 2000), supports these results.

\section{Suggestions for future research}

This study only investigated job level (managers, operational workers and specialist workers) as demographical variable moderating the predictive model of turnover intentions. Future researchers are urged to match other contributing effects of biographical and demographical variables when attempting to explain organisational attitudes and behaviour (such as TIs), taking into account that very little literature on the interaction between these variables and the predictive model of TI is currently available. Future research should also explore the longitudinal implications of biographic and demographic variables on the turnover intentions model as the current study's findings are limited in terms of causal relationship implications. Lastly, it is suggested that research endeavours focus on developing tangible and bestpractice recruitment, selection and retention strategies and talent management interventions that comply with current Employment Equity legislation and are based on the outlined antecedents of TIs within the ICT sector.

\section{Possible limitations of the study}

One limitation of this study is its cross-sectional field survey design, which hinders the credibility of its causal relationships. Longitudinal designs are usually preferred to cross-sectional designs for the establishment of causal relationships. Another limitation is, as Mouton (2001) also pointed out, the fact that an SDA was performed. Possible data collection errors could not be controlled by the authors, and the study was restricted to the original research objectives. A third limitation is the specific focus on an ICT sector sample group. Although the sample size is large $(n=2429)$ and heterogeneous in respect of gender, race, age, marital status, education, and job levels, generalising the results to apply to the population outside the ICT sector company should be done with caution. A fourth limitation is the exclusive use of self-report measures as data collection tools. A certain amount of social desirability, impression management, and random responding are expected in selfreport measures. A fifth limitation refers to strict compliance to Employment Equity Act No. 55 (1998) legislation regarding fair and unbiased selection practices when consulting findings on biographical and demographical indicators to turnover intentions.

\section{Conclusion}

The purpose of the study described in this article was to increase management understanding of sustainability and risk issues relating to people retention in terms of the triple bottom line - profit, people, planet (King III Report, 2009). The study highlighted the moderating role of some biographical and demographical variables in the voluntary employee turnover process. The associated impact of voluntary employee turnover on profit margins is well documented in relevant literature (Bluedorn, 1982; Greyling \& Stanz, 2010; Mobley, 1982).

\section{Acknowledgements}

I would like to thank Roslyn de Braine and Chris Bothma for their kindness in sharing the use of their dataset to conduct the SDA for this study. The research reported in this article is the product of a collaborative research project between the University of Johannesburg and the Vrije Universiteit, Amsterdam. Financial support from SANPAD for conducting this research is hereby acknowledged. Conclusions drawn or opinions expressed in this article are those of the author and do not necessarily reflect the views of SANPAD. A more limited version of this research article was presented as a paper at the XXVIII Pan Pacific Business Conference, 26-29 May 2011, Daejeon, Korea and was also published under the title of: 'The Role of Biographical and Demographical Variables as Moderators in the Prediction of Turnover Intentions' in the Proceedings of the Pan Pacific Conference.

\section{Competing interests}

The authors of this did not receive any funding from any individual or institution in conducting this research. The authors therefore declare that they have no financial or personal relationship(s) which may have inappropriately influenced them in writing this paper.

\section{Authors' contributions}

J.d.P. (University of Johannesburg) was the first author of this article that forms a second (but unrelated part) of a first article by the same authors. J.d.P. conducted this research in the partial fulfillment of her master's degree. In this capacity she conducted the statistical analyses and wrote large portions of the article. G.R. (University of Johannesburg) was the project leader of the SANPAD project and also the supervisor of J.d.P's study. In this capacity he made conceptual contributions to the study and wrote portions of the article.

\section{References}

Almer, E.D., \& Kaplan, S.E. (2002). The effects of flexible work arrangements on stressors, burnout, and behavioral job outcomes in public accounting. Behaviora Research in Accounting, 14, 1-34. http://dx.doi.org/10.2308/bria.2002.14.1.1

Bakker, A.B., \& Demerouti, E. (2006). The job demands-resources model: State of the art. Journal of Managerial Psychology, 22 (3), 309-328. http://dx.doi. org $/ 10.1108 / 02683940710733115$

Bakker, A.B., Schaufeli, W.B., Leiter, M.P., \& Taris, T.W. (2008). Work engagement: An emerging concept in occupational health psychology. Work \& Stress, 22, 187-200. http://dx.doi.org/10.1080/02678370802393649 
Banai, M., \& Reisel, W. (2007). The influence of supportive leadership and job characteristics on work alienation: A six-country investigation. Journal of World Business, 42, 463-476. http://dx.doi.org/10.1016/j.jwb.2007.06.007

Banai, M., Reisel, W.D., \& Probst, T.M. (2004). A managerial and personal control model: predictions of work alienation and organisational commitment in Hungary. Journal of International Management, 10, 375-392. http://dx.doi.org/10.1016/j. intman.2004.05.002

Baron, R.M., \& Kenny, D.A. (1986). The moderator-mediator variable distinction in social psychology research: Conceptual, strategic and statistical considerations. Journal of Personality and Social Psychology, 51, 1173-1182. http://dx.doi. org/10.1037/0022-3514.51.6.1173

Béteille, A. (2002). Work practices and norms: A comparative and historical perspective. International Institute for Labour Studies. Geneva, Switzerland.

Bluedorn, A.C. (1982). Managing turnover strategically. Business Horizons, MarchApril, 6-12. http://dx.doi.org/10.1016/0007-6813(82)90097-0

Bothma, F.C., \& Roodt, G. (2012). Work-based identity and work engagement as potential antecedents of task performance and turnover intention: Unravelling
a complex relationship. SA Journal of Industrial Psychology, 38(1), Art. \#893, 17 a complex relationship. SA Journal of Industrial Psych
pages. http://dx.doi.org/10.4102/sajip. v38i1.893

Burke, R.J., Koyuncu, M., \& Fiksenbaum, L. (2008). Still a man's world: Implications for managerial and professional women in a Turkish bank. Gender in Management: An International Journal, 23, 278-290. http://dx.doi. org/10.1108/17542410810878086

Chiu, Y.L., Chung, R.G., Wu, C.S., \& Ho, C.H. (2009). The effects of job demands, control and social support on hospital clinical nurses' intention to turnover. Applied Nursing Research, 22(4), 258-263. http://dx.doi.org/10.1016/j.apnr.2008.02.006

Chompookum, D., \& Derr, C.B. (2004). The effects of internal career orientations on organizational citizenship behavior in Thailand. Career Development International, 9(4), 406-423. http://dx.doi.org/10.1108/13620430410544355

Cotton, J.L., \& Tuttle, J.M. (1986). Employee turnover: A meta-analysis and review with implications for research. The Academy of Management Review, 11(1), 55-70.

Coyne, I., \& Ong, T. (2007). Organisational citizenship behavior and turnover intention A cross-cultural study. International Journal of Human Resource Management, 18 1085-97. http://dx.doi.org/10.1080/09585190701321831

Cropanzo, R., Rupp, D.E., \& Byrne, Z.S. (2003). The relationship of emotional exhaustion to work attitudes, job performance and organizational citizenship behaviors
Journal of Applied Psychology, 88 (1), 160-169. http://dx.doi.org/10.1037/0021 9010.88.1.160

Denton, D.A., Newton, J.T., \& Bower, E.J. (2008). Occupational burnout and work engagement: A national survey of dentists in the United Kingdom. British Denta Journal, 205, 1-8. http://dx.doi.org/10.1038/sj.bdj.2008.654

Du Plooy, J. (2010). The work engagement - burnout continuum as predictor of turnover intentions. M. Com minor-dissertation, Johannesburg: University of Johannesburg.

Du Plooy, J., \& Roodt, G. (2010). Work engagement, burnout and related constructs as predictors of turnover intentions. SA Journal of Industrial Psychology, 36, 1-13. http://dx.doi.org/10.4102/sajip.v36i1.910

Fang, Y. (2001). Turnover propensity and its causes among Singapore nurses: An empirical study. International Journal of Human Resource Management, 12
859-871.

Frazier, P. A., Tix, A. P., \& Barron, K.E. (2004). Testing moderator and mediator effects in counseling psychology. Journal of Counseling Psychology, 51, 115-134. http:// dx.doi.org/10.1037/0022-0167.51.1.115

Greyling, J., \& Stanz, K. (2010). Turnover of nursing employees in a Gauteng hospital group. SA Journal of Industrial Psychology, 36(1), Art. \#850, 11 pages. http:// dx.doi.org/10.4102/sajip.v36i1.850

Griffeth, R.W., Hom, P.W., \& Gaertner, S. (2000). A meta-analysis of antecedents and correlations of employee turnover: Update, moderator tests, and research
implications for the next millennium. Journal of Management, 26, 463-488. http://dx.doi.org/10.1177/014920630002600305

Hakanen, J.J., Bakker, A.B., \& Schaufeli, W.B. (2006). Burnout and work engagement among teachers. Journal of School Psychology, 43, 495-513. http://dx.doi. org/10.1016/j.jsp.2005.11.001

Hakanen, J.J., Schaufeli, W.B., \& Ahola, K. (2008). The Job-Demands-Resources Model: A three-year cross-lagged study of burnout, depression, commitment and work engagement. Work \& Stress, 22, 224-241. http://dx.doi. org/10.1080/0267837080237943

Harris, K.J., Andrews, M.C., \& Kacmar, K.M. (2007). The moderating effects of justice on the relationship between organizational politics and workplace attitudes.
Journal of Business Psychology, 22, 135-144. http://dx.doi.org/10.1007/s10869Journal of Busi Huffman, A., Youngcourt, S., Payne, S., \& Castro, C. (2008). The importance of
construct breadth when examining interrole conflict. Educational \& Psychological Measurement, 68, 515-530. http://dx.doi.org/10.1177/0013164407308472

Jacobs, E.J. (2005). The development of a predictive model of turnover intentions of professional nurses. Unpublished D Com-thesis, University of Johannesburg, Johannesburg.

Karatepe, O.M., \& Aleshinloye, K.D. (2009). Emotional dissonance and emotional exhaustion among hotel employees in Nigeria. International Journal of Hospitality Management, 28, 349-358. http://dx.doi.org/10.1016/j.ijhm.2008.12.002

Kim, H.J., Shin, K.H., \& Swanger, N. (2009). Burnout and engagement: A comparative analysis using the Big Five personality dimensions. International Journal of Hospitality Management, 28, 96-104. http://dx.doi.org/10.1016/j. ijhm.2008.06.001

King III Report. (2009). Code of Governance Principles for South Africa. King Committee on Governance, III, 1-141.

Korman, A.K., Wittig-Berman, U., \& Lang, D. (1981). Career success and personal Journal, 24, 342-360. http://dx.doi.org/10.2307/255846
Kotzé, K., \& Roodt, G. (2005). Factors that affect the retention of managerial and specialist staff: An exploratory study of an employee commitment model. SA Journal of Human Resource Management, 3, 48-55. http://dx.doi.org/10.4102/ sajhrm.v3i2.65

Kroger, J. (1997). Gender and Identity: The intersection of structure, content and context. Sex Roles, 36(11/12), 747-770. http://dx.doi.org/10.1023/A:1025627206676

Lee, T.W., \& Mitchell, T.R. (1994). An alternative approach: The unfolding model of voluntary employee turnover. Academy of Management Review, 19(1), 51-89. $\mathrm{http}: / /$ dx.doi.org/10.5465/AMR.1994.9410122008

Lee, T.W., Mitchell, T.R., Holtom, B.C., McDaniel, L. S., \& Hill, J. W. (1999). The unfolding model of voluntary turnover: A replication and extension. Academy of Management Journal, 42, 450-462. http://dx.doi.org/10.2307/257015

Martin, A. (2007). Employee perceptions of organisational commitment, job satisfaction and turnover intentions in a post-merger institution. Unpublished $M$ satisfaction and turnover intentions in a post-merger institution. Unpublish
Com-dissertation, University of Johannesburg, Johannesburg, South Africa.

Maslach, C., \& Jackson, S.E. (1981). The measurement of experienced burnout. Journal of Occupational Behaviour, 2, 99-113. http://dx.doi.org/10.1002/ job.4030020205

Maslach, C., Jackson, S.E., \& Leiter, M.P. (1997). Maslach Burnout Inventory (3rd edn.). In C.P. Zalaquett \& R.J. Wood (Eds.), Evaluating stress: A book of resources (pp. 191-218). London: The Scarecrow Press, Inc.

Mauno, S., Kinnunen, U., \& Ruokolainen, M. (2007). Job demands and resources as antecedents of work engagement: A longitudinal study. Journal of Vocational Behavior, 70, 149-171. http://dx.doi.org/10.1016/j.jvb.2006.09.002

Mendes, F., \& Stander, M.W. (2011). Positive organisation: The role of leader behaviour in work engagement and retention. SA Journal of Industrial Psychology, 37(1), Art. \#900, 13 pages, http://dx.doi.org/10.4102/sajip.v37i1.900

Mobley, W. H. (1982). Some unanswered questions in turnover and withdrawal research. Academy of Management Review, 7, 111-116.

Morrell, K., Loan-Clarke, J., Arnold, J., \& Wilkinson, A. (2008). Mapping the Decision to Quit: A Refinement and Test of the Unfolding Model of Voluntary Turnover. Applied Psychology: An International Review, 57(1), 128-150. http://dx.doi. org/10.111/j.146400597.2007.00286.x

Mouton, J. (2001). How to succeed in your master's \& doctoral studies: A South African guide and resource book. Pretoria: Van Schaik Publishers.

Pallant, J. (2007). SPSS survival manual: A step-by-step guide to data analysis using SPSS version 15 (3rd edn.). New York: Open University Press.

Roodt, G. (2004). Turnover intentions. Unpublished Document, University of Johannesburg, Johannesburg, South Africa.

Roodt, G., \& Bothma, F.C. (1997). Die koste van vrywillige, beheerbare arbeidsomset (The cost of voluntary, controlable labour turnover). Journal of Industria Psychology, 23, 26-30.

Rothrauff, T., Abraham, A., Bride, B., \& Roman, P. (2011). Occupational turnover intentions among substance abuse counselors. Journal of Substance Abuse Treatment, 40, 67-76. http://dx.doi.org/10.1016/j.jsat.2010.08.008

Schaufeli, W.B., \& Bakker, A.B. (2003). UWES manual. Utrecht: Occupational Health Psychology Unit, Utrecht University.

Schaufeli, W.B., \& Bakker, A.B. (2004). Job demands, job resources and their relationship with burnout and engagement: A multi-sample study. Journal of Organisational Behavior, 25, 293-315. http://dx.doi.org/10.1002/job.248

Schaufeli, W.B., Salanova, M., González-Romá, V., \& Bakker, A.B. (2002). The measurement of engagement and burnout: A two sample confirmatory facto analytic approach. Journal of Happiness Studies, 3, 71-92. http://dx.doi. org/10.1023/A:1015630930326

Simpson, M.R. (2008). Engagement at work: A review of the literature. International Journal of Nursing Studies, 45, 1-13.

Smith, C. A., Organ, D. W., \& Near, J.P. (1983). Organizational citizenship behavior: Its nature and antecedents. Journal of Applied Psychology, 68, 653-663. http:// Its nature and antecedents. Journal of $A$ ppl
dx.doi.org/10.1037/0021-9010.68.4.653

South Africa, Republic of (1998). Employment Equity Act, No. 55 of 1998. Government Gazette. Vol. 400, No. 19370.

Thomas, A. (2002). Employment equity in South Africa: Lessons from the global school. International Journal of Manpower, 23(3), 237-255. http://dx.doi. org/10.108/01437720210432211

Vallabh, M., \& Donald, F. (2001). A comparison of black and white managers on intent to leave and job mobility. SA Journal of Industrial Psychology, 27(2), 37-42. http:// dx.doi.org/10.4102/sajip.v27i2.784

Van Dyne, L., \& LePine, J.A. (1998). Helping and voice extra-role behaviours: Evidence of construct and predictive validity. Academy of Management Journal, 42, of construct and predictive validity. Acad
$108-119$. http://dx.doi.org/10.2307/256902

Vanheule, S., Rosseel, Y., \& Vlerick, P. (2007). The factorial validity and measurement invariance of the Maslach Burnout Inventory for human services. Stress and Health, 23, 87-91. http://dx.doi.org/10.1002/smi.1124

Weisberg, J., \& Kirschenbaum, A. (1991). Employee turnover intentions: implications from a national sample. International Journal of Human Resource Management 359-375. http://dx.doi.org/10.1080/09585199100000073

Zatzick, D., Elvira, M.M., \& Cohen, L.E. (2003). When is more better? The effects of racial composition of voluntary turnover. Organisation Science, 14(5), 483-496. $\mathrm{http}: / / \mathrm{dx}$.doi.org/10.1287/orsc.14.5.483.16768

Zeffane, R. M. (1994). Understanding employee turnover: The need for a contingency approach. International Journal of Manpower, 15(9/10), 22-37.

Zhen, X.C. \& Francesco, A. (2000). Employee demography, organizational 